\title{
Using Prostatic Fluid Levels of Some Trace Elements and Their Combinations in Non-Invasive and Highly Accurate Screening for Prostate Cancer
}

\author{
Vladimir Zaichick \\ Radionuclide Diagnostics Department, Medical Radiological Research Centre, Obninsk, Russia \\ Email: vzaichick@gmail.com
}

How to cite this paper: Zaichick, V. (2020) Using Prostatic Fluid Levels of Some Trace Elements and Their Combinations in NonInvasive and Highly Accurate Screening for Prostate Cancer. Journal of Cancer Therapy, 11, 1-17.

https://doi.org/10.4236/jct.2020.111001

Received: November 27, 2019

Accepted: December 28, 2019

Published: December 31, 2019

Copyright $\odot 2020$ by author(s) and Scientific Research Publishing Inc. This work is licensed under the Creative Commons Attribution International License (CC BY 4.0).

http://creativecommons.org/licenses/by/4.0/

(c) (i) Open Access

\begin{abstract}
Objective: Prostate specific antigen (PSA) does not provide the high reliability and precision that is required for an accurate screening for prostate cancer (PCa). The aim of our study was to search for a simple, rapid, direct, preferably non-invasive, and highly accurate biomarker and procedure for the screening for PCa. Method: The levels of trace elements (TE) Br, Fe, Rb, Sr, and $\mathrm{Zn}$ were prospectively evaluated in expressed prostatic fluid (EPF). Also $\mathrm{Zn} / \mathrm{Br}, \mathrm{Zn} / \mathrm{Fe}, \mathrm{Zn} / \mathrm{Rb}, \mathrm{Zn} / \mathrm{Sr}$ concentration ratios as well as $\mathrm{ZnRb}$ and $(\mathrm{ZnRb}) / \mathrm{Fe}$ concentration combinations were calculated for EPF samples, obtained from 38 apparently healthy males and from 33, 51, and 24 patients with chronic prostatitis, benign prostatic hyperplasia, and $\mathrm{PCa}$, respectively. Measurements were performed using an energy dispersive X-ray fluorescent (EDXRF) microanalysis. Results: It was found that in the EPF of cancerous prostates the levels of $\mathrm{Rb}, \mathrm{Zn}, \mathrm{Zn} / \mathrm{Br}, \mathrm{Zn} / \mathrm{Fe}, \mathrm{Zn} / \mathrm{Sr}, \mathrm{ZnRb}$, and $(\mathrm{ZnRb}) / \mathrm{Fe}$ were significantly lower in comparison with those in the EPF of normal, inflamed, and hyperplastic prostates. For example, in comparison hyperplastic with cancerous prostates $p$ values obtained using Student's $t$-test and Wilcoxon-Mann-Whitney $U$-test were $<0.01$ and $<0.01$, respectively. It was shown that "Sensitivity", "Specificity" and "Accuracy" of PCa identification using these biomarkers in the EPF samples were all significantly higher than those resulting from of PSA tests in blood serum. Conclusions: The levels of TE and their combinations in EPF, obtained by EDXRF, is a fast, reliable, and non-invasive diagnostic tool that can be successfully used by local, nonurologist physicians at the point-of-care to provide a highly effective PCa screening and as an additional confirmatory test before a prostate gland biopsy.
\end{abstract}




\section{Keywords}

Urology Screening, Prostate Cancer, Expressed Prostatic Fluid, Trace Element Content, Energy-Dispersive X-Ray Fluorescent Analysis

\section{Introduction}

The prostate gland is subject to various disorders and of them, prostate cancer $(\mathrm{PCa})$ is one of the prostate's most important medical, scientific and public health problems. Worldwide, $\mathrm{PCa}$ is the second most commonly diagnosed cancer and the fifth leading cause of cancer deaths in men [1]. PCa is especially prevalent in industrialized countries including North America, Northern and Western Europe and Australia [2]. The American Cancer Society declares PCa, with a lifetime prevalence of one in six men, is the most common cancer in males and the second leading cause of cancer death [3]. Moreover, PCa is the leading cancer in terms of incidence and mortality in men from Africa, Oceania, and the Caribbean [1] [2]. PCa in China has also become a major public health concern [4].

The survival rate is proportional to the stage reached at diagnosis; hence early-stage diagnosis using effective diagnostic tools is a key to reducing mortality due to PCa [5]. It is widely acknowledged that screening and early diagnosis of $\mathrm{PCa}$ are of vital importance for improving the likelihood of recovery. Current screening relies on prostate-specific antigen (PSA) testing in blood serum and a PSA level of $4 \mathrm{ng} / \mathrm{mL}$ is used as the highest level compatible with non-malignant conditions. However, PSA screening of PCa has some significant disadvantages.

Firstly, PSA is not a cancer-specific biomarker. So there can be an elevated serum concentration (above $4 \mathrm{ng} / \mathrm{mL}$ ) among patients with benign prostate hyperplasia $(\mathrm{BPH})$ and urogenital infections, including chronic prostatitis $(\mathrm{CP})$. Reliance on PSA testing can result in significant over-detection of alleged PCa and hence inappropriate treatment of non-malignant disease [6]. Nearly 70\%-75\% of prostate biopsies fail to detect PCa in men who undergo prostate biopsy procedures due to elevated PSA levels discovered after blood serum-test screening [5] [6] [7]. In other words, it has been confirmed that only $25 \%$ - 30\% of patients with a PSA value $\geq 4 \mathrm{ng} / \mathrm{mL}$ were finally diagnosed with $\mathrm{PCa}$, leading to the over-treatment of low-risk patients, unnecessary biopsies and nonessential radical prostatectomies [8]. Thus, the level of PSA test specificity (selectivity) can be estimated as about $25 \%-30 \%$.

Secondly, the PSA test misses some aggressive tumors. For example, as was found by Thompson et al. (2004) that 20\% - 25\% men diagnosed with PCa including those with a poorly differentiated form (Gleason Score $\geq 8$ ) have PSA levels below $4 \mathrm{ng} / \mathrm{mL}$ [6] [9]. Data from other research shows that only $40 \%$ of patients with PCa have an abnormal PSA level [10]. Thus, the PSA test's sensitivity can be estimated as somewhere between $40 \%-75 \%$. 
The limitations and potential harm associated with PSA screening stimulate investigation of novel biomarkers with superior ability to detect $\mathrm{PCa}$, compared with traditional PSA tests, so decreasing unnecessary biopsies. Much attention is now turning to fluid-based biomarkers, because obtaining fluid samples is in effect a minimally invasive liquid biopsy. Other relevant factors of great significance for any novel method of PCa detection include cost-effectiveness, capacity to generate real-time results, "simplicity-of-use", robustness, and functionality without excessive prior-processing of samples [11].

In our previous studies the significant involvement of $\mathrm{Zn}, \mathrm{Ca}, \mathrm{Mg}, \mathrm{Rb}$ and some other trace elements (TEs) in the function of the prostate was studied. [12]-[22]. One of the main functions of the prostate gland is the production of prostatic fluid [23]. It contains a high concentration of $\mathrm{Zn}$ and elevated levels of $\mathrm{Ca}, \mathrm{Mg}, \mathrm{Rb}$, and some other TEs, in comparison with levels in serum and other human body fluids.

The first finding of remarkably high levels of $\mathrm{Zn}$ in human expressed prostatic fluid (EPF) was reported in the early 1960s [24]. After analyzing EPF expressed from the prostates of 8 apparently healthy men, aged 25 - 55 years, it was found that $\mathrm{Zn}$ concentrations varied from 300 to $730 \mathrm{mg} / \mathrm{L}$. After this finding several investigators suggested that the measurement of $\mathrm{Zn}$ levels in EPF may be useful as a marker of abnormal prostate secretory function [25] [26]. This suggestion promoted more detailed studies of the $\mathrm{Zn}$ concentrations in the EPF of healthy subjects and in those with different prostatic diseases, including PCa [26] [27]. A detailed review of these studies, reflecting the contradictions within accumulated data, was given in our earlier publication [27]. Moreover, the method and apparatus for micro analysis of $\mathrm{Br}, \mathrm{Fe}, \mathrm{Rb}, \mathrm{Sr}$, and $\mathrm{Zn}$ in the EPF samples using energy dispersive $\mathrm{X}$-ray fluorescence (EDXRF) activated by radiation from the radionuclide source ${ }^{109} \mathrm{Cd}\left({ }^{109} \mathrm{Cd}\right.$ EDXRF) was developed by us [28]. We reasoned that apart from total amounts of TEs the ratios of $\mathrm{Zn}$ to some other TE content in EPF are likely to reflect a disturbance of prostate function. It was found that data on changes of TE content and $\mathrm{Zn} / \mathrm{TE}$ concentration ratios in EPF of patients with PCa are very important, because these significant changes increase our knowledge and recognition of PCa pathogenesis and may prove useful as PCa diagnostic markers [29]-[39].

The present study had three aims. The main objective was to obtain reliable results about the $\mathrm{Br}, \mathrm{Fe}, \mathrm{Rb}, \mathrm{Sr}$, and $\mathrm{Zn}$ concentrations in the EPF of healthy men as well as in the EPF of patients with CP, BPH and PCa using the ${ }^{109} \mathrm{Cd}$ EDXRF method. The second aim was to calculate $\mathrm{Zn} / \mathrm{TE}$ concentration ratios, $\mathrm{ZnRb}$ concentration combination, and also the $(\mathrm{ZnRb}) / \mathrm{Fe}$ concentration combination and to compare the levels of all EPF parameters investigated for normal, inflamed, hyperplastic, and cancerous prostates. The final aim was to select the optimal PCa biomarker among the TEs' concentrations, $\mathrm{Zn} / \mathrm{TE}$ concentration ratios, and other Zn-TE concentration combinations by evaluating appropriate characteristics of each potential diagnostic test, with regard to its sensitivity, specificity, and accuracy. 
All studies were approved by the Ethical Committees of the Medical Radiological Research Centre, Obninsk. All the procedures performed in studies involving human participants were in accordance with the ethical standards of the institutional and/or national research committee and with the 1964 Helsinki declaration and its later amendments, or with comparable ethical standards.

\section{Materials and Methods}

\subsection{Specimens of EPF and Their Preparation for TE Analysis}

Specimens of EPF were obtained from 38 men with apparently normal prostates (N, mean age \pm Standard Deviation: $59 \pm 11$ years, range $41-82$ years), from 33 males with CP (mean age $50 \pm 9$ years, range $37-65$ years), from 51 patients with BPH (mean age $63 \pm 6$ years, range $52-75$ years), and from 24 patients with PCa (mean age $65 \pm 10$ years, range $47-77$ years) in the Urological Department of the Medical Radiological Research Centre (MRRC) using a standard rectal massage procedure. The diagnosis of each prostate condition was made by qualified urologists. In all cases the $\mathrm{N}$ classification and $\mathrm{CP}$ diagnosis were confirmed by clinical examination and by cytological and bacteriological investigations of the EPF samples. The diagnosis of BPH or PCa had been confirmed by clinical examination and morphological results obtained during studies of biopsy and resected materials. Subjects were asked to abstain from sexual intercourse for three days preceding the procedure. Subjects who used Zn or other TEs supplements were excluded. Specimens of EPF were obtained in sterile containers, which were appropriately labeled. Twenty $\mu \mathrm{L}$ (microliters) of fluid were taken in duplicate by micropipette from every specimen for TE analysis, while the rest of the fluid was used for cytological and bacteriological investigations. One $20 \mu \mathrm{L}$ sample of the EPF was dropped on an $11.3 \mathrm{~mm}$ diameter disk made of thin, ash-free filter paper fixed on pieces of adhesive tape and dried in a desiccator at room temperature. Then the dried sample was covered with a $4 \mu \mathrm{m}$ gage Dacron film and centrally pulled onto a Plexiglas cylindrical frame [28].

\subsection{Certified Reference Material}

To determine concentration of the TEs by comparison with known standards, aliquots of solutions of commercial, chemically pure compounds were used for calibration [40]. The standard samples for calibration were prepared in the same way as the samples of prostate fluid. Because there were no available liquid Certified Reference Materials (CRMs), ten sub-samples of the powdered CRM IAEA $\mathrm{H}-4$ (animal muscle) were analyzed to estimate the precision and accuracy of results. Every CRM sub-sample weighing about $3 \mathrm{mg}$ was applied to the piece of adhesive tape serving as an adhesive fixing backing. An acrylic stencil made in the form of a thin-walled cylinder with $11.3 \mathrm{~mm}$ inner diameter was used to apply the sub-sample to the adhesive tape. The polished-end acrylic pestle, which is a constituent of the stencil set, was used for uniform distribution of the subsample upon the adhesive tape surface restricted by the stencil's inner cylindrical 
surface. After the sub-sample was lightly pressed onto the adhesive tape carrier, the stencil was removed. Then the sub-sample was covered with $4 \mu \mathrm{m}$ gage_Dacron film. Before the sample was applied, pieces of adhesive tape and Dacron film were weighed using an analytical balance. They were reweighed after the sample had been placed inside to determine precisely the sub-sample mass.

\subsection{Radionuclide-Induced EDXRF Microanalysis}

The facility for the radionuclide-induced EDXRF included an annular ${ }^{109} \mathrm{Cd}$ source with an activity of $2.56 \mathrm{GBq}, \mathrm{A} \mathrm{Si}$ (Li) detector with an electric cooling system and a portable multi-channel analyzer based on a personal computer, comprised the detection system. Its resolution was $270 \mathrm{eV}$ at the $6.4 \mathrm{keV}$ line. The facility functioned as follows. Photons with energy $22.1 \mathrm{keV}$ from the ${ }^{109} \mathrm{Cd}$ source arrived at the surface of the specimen inducing fluorescent $\mathrm{K}_{\alpha} \mathrm{X}$-rays from the TE. The fluorescence reached the detector after passing through a 10 $\mathrm{mm}$ diameter collimator. Then the X-ray's arrival was recorded. The duration of the measurements of $\mathrm{Br}, \mathrm{Fe}, \mathrm{Rb}, \mathrm{Sr}$, and $\mathrm{Zn}$ concentrations was $60 \mathrm{~min}$ for each sample. The intensity of the $\mathrm{K}_{\alpha}$-line of $\mathrm{Br}, \mathrm{Fe}, \mathrm{Rb}, \mathrm{Sr}$, and $\mathrm{Zn}$ for EPF samples and standards was estimated from a calculation of the total area under the corresponding photopeaks in the spectra. More detail information about the radionuclide-induced EDXRF microanalysis developed by us was presented in our previous publication [28].

\subsection{Statistical Analysis}

All EPF samples for EDXRF were prepared in duplicate and mean values of TE contents were used in the final calculation. Using the Microsoft Office Excel programs, some statistical characteristics, such as arithmetic mean (M), standard deviation (SD), standard error of the mean (SEM), minimum and maximum values (Range), and median were calculated for $\mathrm{TE}$ concentrations, for the $\mathrm{Zn} / \mathrm{Br}$, $\mathrm{Zn} / \mathrm{Fe}, \mathrm{Zn} / \mathrm{Rb}, \mathrm{Zn} / \mathrm{Sr}$ ratios and for the $\mathrm{ZnRb}$ and $(\mathrm{ZnRb}) / \mathrm{Fe}$ concentration combinations in the EPF of normal $(\mathrm{N}), \mathrm{CP}, \mathrm{BPH}$ and PCa prostates. The difference in the results between the five pairs of samples ( $\mathrm{N}$ and $\mathrm{CP}, \mathrm{N}$ and $\mathrm{BPH}, \mathrm{N}$ and $\mathrm{PCa}, \mathrm{PCa}$ and $\mathrm{CP}, \mathrm{PCa}$ and $\mathrm{BPH}$ ) was evaluated by the parametric Student's t-test and non-parametric Wilcoxon-Mann-Whitney $U$-test. Values of $p<0.05$ were considered to be statistically significant. For the construction of diagrams illustrating individual data sets for TE concentrations and their combinations in the EPF of normal, inflamed, benign hyperplastic and cancerous prostates, the Microsoft Office Excel software was also used.

\section{Results}

Table 1 and Table 2 depict some statistical characteristics of the parameters investigated and relevant to a normal distribution (M, SD, and SEM) (Table 1) and appropriate for a distribution that may not necessarily be normal (Median, Range) (Table 2). 
Table 1. Mean values of the $\mathrm{Br}, \mathrm{Fe}, \mathrm{Rb}, \mathrm{Sr}$, and $\mathrm{Zn}$ concentrations $(\mathrm{mg} / \mathrm{L})$ and also some $\mathrm{Zn}$ to TE concentration ratios and TE level combinations in EPF from normal (N), inflamed (CP), benign hyperplastic (BPH) and cancerous prostates (PCa).

\begin{tabular}{ccccc}
\hline & \multicolumn{4}{c}{ Prostate fluid } \\
\cline { 2 - 5 } $\begin{array}{c}\text { Element } \\
\text { or TE } \\
\text { Combination }\end{array}$ & $\begin{array}{c}41-82 \text { years } \\
(\mathrm{n}=38)\end{array}$ & $\begin{array}{c}\text { CP }-65 \text { years } \\
(\mathrm{n}=33)\end{array}$ & $\begin{array}{c}52-75 \text { years } \\
(\mathrm{n}=51)\end{array}$ & $\begin{array}{c}47-77 \text { years } \\
(\mathrm{n}=24)\end{array}$ \\
\cline { 2 - 5 } & Mean $\pm \mathrm{SD}(\mathrm{SEM})$ & Mean $\pm \mathrm{SD}(\mathrm{SEM})$ & Mean $\pm \mathrm{SD}(\mathrm{SEM})$ & Mean \pm SD (SEM) \\
\hline $\mathrm{Br}$ & $2.86 \pm 2.93(0.59)$ & $3.35 \pm 2.64(0.69)$ & $2.32 \pm 1.84(0.30)$ & $4.51 \pm 7.19(2.27)$ \\
$\mathrm{Fe}$ & $8.30 \pm 7.62(1.42)$ & $10.9 \pm 9.6(2.3)$ & $11.5 \pm 10.8(1.8)$ & $21.7 \pm 28.8(8.7)$ \\
$\mathrm{Rb}$ & $1.16 \pm 0.52(0.10)$ & $2.32 \pm 1.13(0.30)$ & $1.70 \pm 1.41(0.23)$ & $0.53 \pm 0.38(0.11)$ \\
$\mathrm{Sr}$ & $1.27 \pm 0.84(0.17)$ & $1.57 \pm 1.36(0.79)$ & $1.41 \pm 1.09(0.26)$ & $1.70 \pm 2.15(0.76)$ \\
$\mathrm{Zn}$ & $598 \pm 207(34)$ & $382 \pm 275(48)$ & $488 \pm 302(42)$ & $62.0 \pm 98.3(20.1)$ \\
$\mathrm{Zn} / \mathrm{Br}$ & $639 \pm 610(122)$ & $129 \pm 96(32)$ & $437 \pm 545(88)$ & $18.5 \pm 25.7(8.1)$ \\
$\mathrm{Zn} / \mathrm{Fe}$ & $120 \pm 97(19)$ & $35.9 \pm 20.6(5.3)$ & $92 \pm 117(19)$ & $2.99 \pm 4.37(1.32)$ \\
$\mathrm{Zn} / \mathrm{Rb}$ & $637 \pm 372(69)$ & $175 \pm 101(29)$ & $471 \pm 459(74)$ & $900 \pm 2540(733)$ \\
$\mathrm{Zn} / \mathrm{Sr}$ & $733 \pm 570(116)$ & $484 \pm 732(422)$ & $596 \pm 787(191)$ & $36.8 \pm 54.9(19.2)$ \\
$\mathrm{ZnRb}$ & $684 \pm 374(69)$ & $1239 \pm 1130(302)$ & $1077 \pm 1337(217)$ & $19.2 \pm 34.2(9.9)$ \\
$(\mathrm{ZnRb}) / \mathrm{Fe}$ & $174 \pm 206(40)$ & $111 \pm 105(29)$ & $158 \pm 188(32)$ & $0.98 \pm 11.0(0.48)$ \\
\hline
\end{tabular}

Mean—arithmetic mean, SD—standard deviation, SEM—standard error of mean.

Table 2. Median and range of the $\mathrm{Br}, \mathrm{Fe}, \mathrm{Rb}, \mathrm{Sr}$, and $\mathrm{Zn}$ concentrations $(\mathrm{mg} / \mathrm{L})$ and also $\mathrm{Zn}$ to TE concentration ratios and TE level combinations in EPF from normal (N), inflamed (CP), benign hyperplastic (BPH) and cancerous prostates (PCa).

\begin{tabular}{|c|c|c|c|c|}
\hline \multirow{5}{*}{$\begin{array}{c}\text { Element } \\
\text { or TE } \\
\text { Combination }\end{array}$} & \multicolumn{4}{|c|}{ Prostate fluid } \\
\hline & $\mathrm{N}$ & $\mathrm{CP}$ & $\mathrm{BPH}$ & $\mathrm{PCa}$ \\
\hline & $41-82$ years & $37-65$ years & $52-75$ years & $47-77$ years \\
\hline & $(\mathrm{n}=38)$ & $(\mathrm{n}=33)$ & $(\mathrm{n}=51)$ & $(\mathrm{n}=24)$ \\
\hline & Median (Range) & Median (Range) & Median (Range) & Median (Range) \\
\hline $\mathrm{Br}$ & $1.20(0.490-8.53)$ & $2.98(0.120-9.85)$ & $1.62(0.230-8.70)$ & $2.08(0.697-24.3)$ \\
\hline $\mathrm{Fe}$ & $7.33(1.27-39.8)$ & $6.97(3.85-41.9)$ & $9.31(1.06-54.1)$ & $13.9(7.70-107)$ \\
\hline $\mathrm{Rb}$ & $1.03(0.376-2.45)$ & $1.75(0.730-4.54)$ & $1.46(0.210-5.04)$ & $0.422(0.013-1.39)$ \\
\hline $\mathrm{Sr}$ & $1.18(0.400-3.44)$ & $1.58(0.210-2.93)$ & $1.12(0.230-4.79)$ & $0.872(0.230-6.83)$ \\
\hline $\mathrm{Zn}$ & $560(253-948)$ & $295(62.0-1051)$ & $427(45.0-977)$ & $21.6(2.82-371)$ \\
\hline $\mathrm{Zn} / \mathrm{Br}$ & $439(43.0-1882)$ & $103(14.1-322)$ & $219(10.5-2416)$ & $6.86(0.389-68.3)$ \\
\hline $\mathrm{Zn} / \mathrm{Fe}$ & $77.0(13.0-343)$ & $33.7(7.03-66.3)$ & $43.2(2.81-508)$ & $0.766(0.237-13.0)$ \\
\hline $\mathrm{Zn} / \mathrm{Rb}$ & $536(119-1612)$ & $154(41.3-381)$ & $283(49.0-1809)$ & $23.8(6.77-8840)$ \\
\hline $\mathrm{Zn} / \mathrm{Sr}$ & $602(155-2321)$ & $88.2(34.6-1329)$ & $277(71.0-3361)$ & $16.8(2.20-163)$ \\
\hline $\mathrm{ZnRb}$ & $568(209-1716)$ & $854(93.0-3183)$ & $514(37.5-4763)$ & $3.26(1.12-114)$ \\
\hline$(\mathrm{ZnRb}) / \mathrm{Fe}$ & $88.0(15.0-811)$ & $107(9.49-302)$ & $68.8(0.903-736)$ & $0.256(0.094-5.46)$ \\
\hline
\end{tabular}

The ratios of means/medians and the difference between mean/median values of all investigated parameters ( $\mathrm{Br}, \mathrm{Fe}, \mathrm{Rb}, \mathrm{Sr}, \mathrm{Zn}, \mathrm{Zn} / \mathrm{Br}, \mathrm{Zn} / \mathrm{Fe}, \mathrm{Zn} / \mathrm{Rb}, \mathrm{Zn} / \mathrm{Sr}$, 
$\mathrm{ZnRb},(\mathrm{ZnRb}) / \mathrm{Fe})$ in EPF samples of normal, inflamed, benign hyperplastic and cancerous prostates determined by the parametric Student's $t$-test and non-parametric Wilcoxon-Mann-Whitney $U$-test are presented in Table 3 and Table 4, respectively.

Table 5 contains important parameters ("Sensitivity", "Specificity" and "Accuracy"), which reflect the possibilities that some TE concentrations and their combinations in prostate fluid can aid the diagnosis of $\mathrm{PCa}$ (an estimation was made for "PCa or normal, $\mathrm{CP}$, and $\mathrm{BPH}$ "). A calculation was done under such conditions as: if the level of "Sensitivity" was chosen as $100 \%$, if the level of "Specificity" was chosen as $100 \%$, and if the level of "Sensitivity" was not below $80 \%$ (optimal).

Individual data sets for the most informative TEs and their combinations ( $\mathrm{Rb}$, $\mathrm{Zn}, \mathrm{Zn} / \mathrm{Br}, \mathrm{Zn} / \mathrm{Fe}, \mathrm{Zn} / \mathrm{Sr}, \mathrm{ZnRb},(\mathrm{ZnRb}) / \mathrm{Fe}$ ) investigated in $\mathrm{EPF}$ samples of normal, inflamed, benign hyperplastic and cancerous prostates are shown in Figure 1.

\section{Discussion}

As was shown by us [27]-[39] results from the use of CRM IAEA H-4 as certified reference materials for the analysis of samples of EPF is acceptable. Good agreement of the $\mathrm{Br}, \mathrm{Fe}, \mathrm{Rb}, \mathrm{Sr}$, and $\mathrm{Zn}$ contents, analyzed by the ${ }^{109} \mathrm{Cd} \mathrm{EDXRF}$ method, with the certified data of reference materials indicates an acceptable accuracy for the results obtained in the study of TEs of the EPF presented in Tables 1-5.

Table 3. Ratio of means and the difference (Student's $t$-test) between mean values of the $\mathrm{Br}, \mathrm{Fe}, \mathrm{Rb}, \mathrm{Sr}$, and $\mathrm{Zn}$ concentrations $(\mathrm{mg} / \mathrm{L})$ and also $\mathrm{Zn}$ to TE concentration ratios and TE level combinations in EPF from normal (N), inflamed (CP), benign hyperplastic (BPH) and cancerous prostates $(\mathrm{PCa})$.

\begin{tabular}{ccccccccccc}
\hline \multirow{2}{*}{$\begin{array}{c}\text { Element } \\
\text { or TE } \\
\text { Combination }\end{array}$} & \multicolumn{2}{c}{$\mathrm{CP}$ and N } & \multicolumn{2}{c}{$\mathrm{BPH}$ and N } & \multicolumn{2}{c}{ PCa and N } & \multicolumn{2}{c}{ PCa and CP } & \multicolumn{2}{c}{ PCa and BPH } \\
\cline { 2 - 12 } & CP/N & $p \leq$ & $\begin{array}{c}\text { Ratio } \\
\text { BPH/N }\end{array}$ & $p \leq$ & $\begin{array}{c}\text { Ratio } \\
\text { PCa/N }\end{array}$ & $p \leq$ & $\begin{array}{c}\text { Ratio } \\
\text { PCa/CP }\end{array}$ & $p \leq$ & $\begin{array}{c}\text { Ratio } \\
\text { PCa/BPH }\end{array}$ & $p \leq$ \\
\hline $\mathrm{Br}$ & 1.17 & 0.59 & 0.81 & 0.41 & 1.58 & 0.50 & 1.35 & 0.64 & 1.94 & 0.36 \\
$\mathrm{Fe}$ & 1.31 & 0.35 & 1.39 & 0.17 & 2.61 & 0.16 & 1.99 & 0.25 & 1.89 & 0.27 \\
$\mathrm{Rb}$ & 2.00 & $\mathbf{0 . 0 1}$ & 1.47 & $\mathbf{0 . 0 3}$ & 0.46 & $\mathbf{0 . 0 1}$ & 0.23 & $\mathbf{0 . 0 1}$ & 0.31 & $\mathbf{0 . 0 1}$ \\
$\mathrm{Sr}$ & 1.24 & 0.74 & 1.11 & 0.66 & 1.34 & 0.60 & 1.08 & 0.93 & 1.21 & 0.73 \\
$\mathrm{Zn}$ & 0.64 & $\mathbf{0 . 0 1}$ & 0.82 & $\mathbf{0 . 0 4}$ & 0.104 & $\mathbf{0 . 0 1}$ & 0.16 & $\mathbf{0 . 0 1}$ & 0.13 & $\mathbf{0 . 0 1}$ \\
$\mathrm{Zn} / \mathrm{Br}$ & 0.20 & $\mathbf{0 . 0 1}$ & 0.68 & 0.19 & 0.029 & $\mathbf{0 . 0 1}$ & 0.14 & $\mathbf{0 . 0 1}$ & 0.042 & $\mathbf{0 . 0 1}$ \\
$\mathrm{Zn} / \mathrm{Fe}$ & 0.30 & $\mathbf{0 . 0 1}$ & 0.77 & 0.31 & 0.025 & $\mathbf{0 . 0 1}$ & 0.083 & $\mathbf{0 . 0 1}$ & 0.033 & $\mathbf{0 . 0 1}$ \\
$\mathrm{Zn} / \mathrm{Rb}$ & 0.27 & $\mathbf{0 . 0 1}$ & 0.74 & 0.11 & 1.41 & 0.73 & 5.14 & 0.34 & 1.91 & 0.57 \\
$\mathrm{Zn} / \mathrm{Sr}$ & 0.66 & 0.62 & 0.81 & 0.55 & 0.050 & $\mathbf{0 . 0 1}$ & 0.076 & 0.40 & 0.062 & $\mathbf{0 . 0 1}$ \\
$\mathrm{ZnRb}$ & 1.81 & 0.10 & 1.57 & 0.09 & 0.028 & $\mathbf{0 . 0 1}$ & 0.015 & $\mathbf{0 . 0 1}$ & 0.018 & $\mathbf{0 . 0 1}$ \\
$\mathrm{ZnRb} / \mathrm{Fe}$ & 0.64 & 0.21 & 0.91 & 0.75 & 0.0056 & $\mathbf{0 . 0 1}$ & 0.0088 & $\mathbf{0 . 0 1}$ & 0.0062 & $\mathbf{0 . 0 1}$ \\
\hline
\end{tabular}

Data in Bold indicated significant differences. 
Table 4. Ratio of medians and the difference (Wilcoxon-Mann-Whitney $U$-test) between mean values of the $\mathrm{Br}, \mathrm{Fe}, \mathrm{Rb}, \mathrm{Sr}$, and also $\mathrm{Zn}$ to $\mathrm{TE}$ concentration ratios and TE level combinations in EPF from normal $(\mathrm{N})$, inflamed $(\mathrm{CP})$, benign hyperplastic (BPH) and cancerous prostates $(\mathrm{PCa})$.

\begin{tabular}{|c|c|c|c|c|c|c|c|c|c|c|}
\hline \multirow{2}{*}{$\begin{array}{c}\text { Element } \\
\text { or TE } \\
\text { Combination }\end{array}$} & \multicolumn{2}{|c|}{$\mathrm{CP}$ and $\mathrm{N}$} & \multicolumn{2}{|c|}{$\mathrm{BPH}$ and $\mathrm{N}$} & \multicolumn{2}{|c|}{$\mathrm{PCa}$ and $\mathrm{N}$} & \multicolumn{2}{|c|}{$\mathrm{PCa}$ and $\mathrm{CP}$} & \multicolumn{2}{|c|}{$\mathrm{PCa}$ and $\mathrm{BPH}$} \\
\hline & $\begin{array}{l}\text { Ratio } \\
\mathrm{CP} / \mathrm{N}\end{array}$ & $p$ & $\begin{array}{c}\text { Ratio } \\
\mathrm{BPH} / \mathrm{N}\end{array}$ & $p$ & $\begin{array}{c}\text { Ratio } \\
\mathrm{PCa} / \mathrm{N}\end{array}$ & $p$ & $\begin{array}{c}\text { Ratio } \\
\mathrm{PCa} / \mathrm{CP}\end{array}$ & $p$ & $\begin{array}{c}\text { Ratio } \\
\mathrm{PCa} / \mathrm{BPH}\end{array}$ & $p$ \\
\hline $\mathrm{Br}$ & 2.48 & $>0.05$ & 1.35 & $>0.05$ & 1.73 & $>0.05$ & 0.70 & $>0.05$ & 1.28 & $>0.05$ \\
\hline $\mathrm{Fe}$ & 0.95 & $>0.05$ & 1.27 & $>0.05$ & 1.90 & $>0.05$ & 1.99 & $>0.05$ & 1.49 & $>0.05$ \\
\hline $\mathrm{Rb}$ & 1.70 & $<0.01$ & 1.42 & $<0.01$ & 0.41 & $<0.01$ & 0.24 & $<0.01$ & 0.29 & $<0.01$ \\
\hline $\mathrm{Sr}$ & 1.34 & $>0.05$ & 0.95 & $>0.05$ & 0.74 & $>0.05$ & 0.55 & $>0.05$ & 0.78 & $>0.05$ \\
\hline $\mathrm{Zn}$ & 0.53 & $<0.01$ & 0.76 & $<0.01$ & 0.039 & $<0.01$ & 0.073 & $<0.01$ & 0.051 & $<0.01$ \\
\hline $\mathrm{Zn} / \mathrm{Br}$ & 0.23 & $<0.01$ & 0.50 & $>0.05$ & 0.016 & $<0.01$ & 0.067 & $<0.01$ & 0.031 & $<0.01$ \\
\hline $\mathrm{Zn} / \mathrm{Fe}$ & 0.44 & $<0.01$ & 0.56 & $>0.05$ & 0.0099 & $<0.01$ & 0.023 & $<0.01$ & 0.018 & $<0.01$ \\
\hline $\mathrm{Zn} / \mathrm{Rb}$ & 0.29 & $<0.01$ & 0.53 & $>0.05$ & 0.044 & $>0.05$ & 0.15 & $>0.05$ & 0.084 & $>0.05$ \\
\hline $\mathrm{Zn} / \mathrm{Sr}$ & 0.15 & $>0.05$ & 0.46 & $>0.05$ & 0.028 & $<0.01$ & 0.19 & $>0.05$ & 0.061 & $<0.01$ \\
\hline $\mathrm{ZnRb}$ & 1.50 & $>0.05$ & 0.90 & $>0.05$ & 0.0057 & $<0.01$ & 0.0038 & $<0.01$ & 0.0063 & $<0.01$ \\
\hline$(\mathrm{ZnRb}) / \mathrm{Fe}$ & 1.22 & $>0.05$ & 0.78 & $>0.05$ & 0.0029 & $<0.01$ & 0.0024 & $<0.01$ & 0.0037 & $<0.01$ \\
\hline
\end{tabular}

Data in Bold indicated significant differences.

Table 5. Parameters of the importance ("Specificity" and "Accuracy") of some TE concentrations and their combinations in EPF for the diagnosis of PCa (an estimation is made for "PCa or normal, $\mathrm{CP}$, and $\mathrm{BPH}$ ").

\begin{tabular}{|c|c|c|c|c|c|}
\hline $\begin{array}{c}\text { Chosen } \\
\text { parameter(s) }\end{array}$ & $\begin{array}{l}\text { TE concentration } \\
\text { or their combinations }\end{array}$ & $\begin{array}{l}\text { Upper limit } \\
\text { for PCa }\end{array}$ & $\begin{array}{c}\text { Sensitivity } \\
\%\end{array}$ & $\begin{array}{c}\text { Specificity } \\
\%\end{array}$ & $\begin{array}{c}\text { Accuracy } \\
\%\end{array}$ \\
\hline \multicolumn{6}{|c|}{ "Sensitivity" was chosen as $100 \%$} \\
\hline & $\mathrm{Rb}$ & $1.39 \mathrm{mg} / \mathrm{L}$ & 100 & $49 \pm 6$ & $55 \pm 5$ \\
\hline & $\mathrm{Zn}$ & $371 \mathrm{mg} / \mathrm{L}$ & 100 & $60 \pm 5$ & $66 \pm 5$ \\
\hline & $\mathrm{Zn} / \mathrm{Br}$ & 68.3 & 100 & $78 \pm 5$ & $80 \pm 4$ \\
\hline & $\mathrm{Zn} / \mathrm{Fe}$ & 13.1 & 100 & $90 \pm 3$ & $91 \pm 3$ \\
\hline & $\mathrm{Zn} / \mathrm{Sr}$ & 163 & 100 & $80 \pm 6$ & $83 \pm 5$ \\
\hline & $\mathrm{ZnRb}$ & 115 & 100 & $89 \pm 4$ & $90 \pm 3$ \\
\hline & $(\mathrm{ZnRb}) / \mathrm{Fe}$ & 5.5 & 100 & $96 \pm 2$ & $96 \pm 2$ \\
\hline \multicolumn{6}{|c|}{ "Specificity" was chosen as $100 \%$} \\
\hline & $\mathrm{Rb}$ & $0.20 \mathrm{mg} / \mathrm{L}$ & $17 \pm 11$ & 100 & $89 \pm 3$ \\
\hline & $\mathrm{Zn}$ & $45.0 \mathrm{mg} / \mathrm{L}$ & $63 \pm 10$ & 100 & $94 \pm 2$ \\
\hline & $\mathrm{Zn} / \mathrm{Br}$ & 10.5 & $70 \pm 15$ & 100 & $90 \pm 3$ \\
\hline & $\mathrm{Zn} / \mathrm{Fe}$ & 2.8 & $73 \pm 14$ & 100 & $90 \pm 3$ \\
\hline & $\mathrm{Zn} / \mathrm{Sr}$ & 34 & $75 \pm 16$ & 100 & $96 \pm 3$ \\
\hline & $\mathrm{ZnRb}$ & 37 & $83 \pm 11$ & 100 & $98 \pm 2$ \\
\hline & $(\mathrm{ZnRb}) / \mathrm{Fe}$ & 0.90 & $73 \pm 14$ & 100 & $96 \pm 2$ \\
\hline
\end{tabular}




\section{Continued}

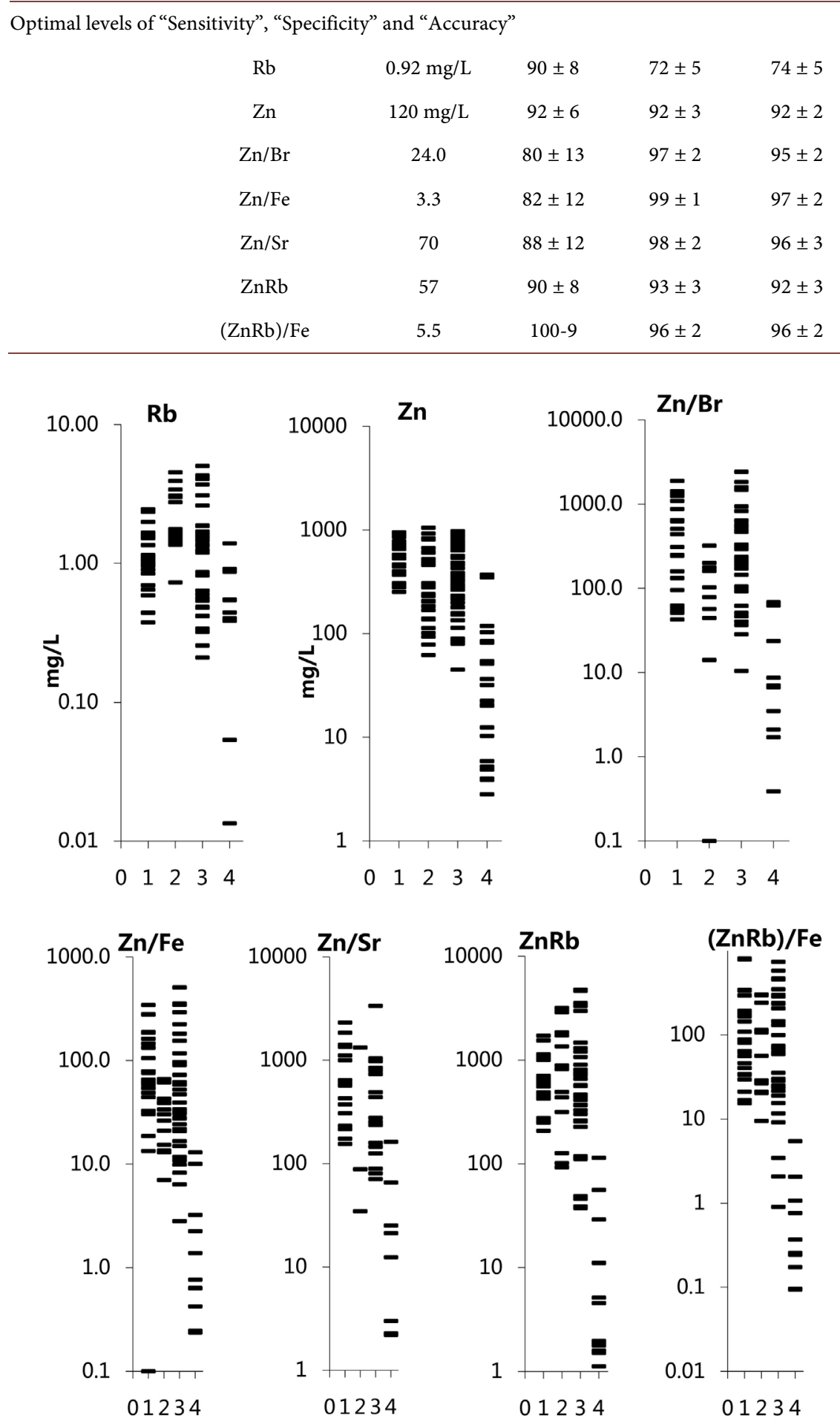

Figure 1. Individual data sets for $\mathrm{Zn}$ and $\mathrm{Rb}$ concentrations (mg/L), $\mathrm{Zn} / \mathrm{Br}, \mathrm{Zn} / \mathrm{Fe}$, and $\mathrm{Zn} / \mathrm{Sr}$ ratios, $\mathrm{ZnRb}$ multiplications, and also for $(\mathrm{ZnRb}) / \mathrm{Fe}$ combination in prostate fluid of normal (1), inflamed (2), benign hyperplastic (3) and cancerous prostate (4).

From Table 3 and Table 4, it is observed that in the EPF of inflamed prostates the mean/median values for the $\mathrm{Br}, \mathrm{Fe}, \mathrm{Sr}, \mathrm{Zn} / \mathrm{Sr}, \mathrm{ZnRb}$, and $(\mathrm{ZnRb}) / \mathrm{Fe}$ do not 
differ significantly from normal levels, but the value of $\mathrm{Rb}$ is higher $(p<0.01)$, while the values of $\mathrm{Zn} / \mathrm{Br}, \mathrm{Zn} / \mathrm{Fe}, \mathrm{Zn} / \mathrm{Rb}$, and $\mathrm{Zn} / \mathrm{Sr}$ are significantly $(p<0.01)$ lower.

In the EPF from hyperplastic prostates the mean/median values for $\mathrm{Br}, \mathrm{Fe}, \mathrm{Sr}$, $\mathrm{Zn} / \mathrm{Br}, \mathrm{Zn} / \mathrm{Fe}, \mathrm{Zn} / \mathrm{Rb}, \mathrm{Zn} / \mathrm{Sr}, \mathrm{ZnRb}$, and (ZnRb)/Fe are not significantly different from normal levels, but the value of $\mathrm{Rb}$ is higher $(p<0.03 t$-test and $p<0.01$ $U$-test), while the values of $\mathrm{Zn}$ is significantly $(p<0.04 t$-test and $p<0.01$ $U$-test) lower (Table 3 and Table 4).

In the $\mathrm{EPF}$ of cancerous prostates the mean/median values for the $\mathrm{Br}, \mathrm{Fe}, \mathrm{Sr}$, and $\mathrm{Zn} / \mathrm{Rb}$, do not differ significantly from normal levels, but the values of $\mathrm{Rb}$, $\mathrm{Zn}, \mathrm{Zn} / \mathrm{Br}, \mathrm{Zn} / \mathrm{Fe}, \mathrm{Zn} / \mathrm{Sr}, \mathrm{ZnRb}$, and $(\mathrm{ZnRb}) / \mathrm{Fe}$ are significantly $(p<0.01 t$-test and $p<0.01 U$-test) lower. Moreover, these differences also exist when EPFs of cancerous prostates are compared with EPFs of inflamed or hyperplastic prostates. The only exception is the $\mathrm{Zn} / \mathrm{Sr}$ ratio when $\mathrm{EPF}$ of cancerous prostates are compared with those of inflamed glands (Table 3 and Table 4).

Thus, from Table 3 and Table 4, it is observed that measurements of the TE concentrations, $\mathrm{Zn} / \mathrm{TE}$ concentration ratios, and some other TE combinations in EPF could become a powerful diagnostic tool when seeking PCa. To a large extent, continuation of the search for new methods for early diagnosis of PCa was due to experience gained after a critical assessment of the limitations of the current PSA blood serum tests [5]-[11] [41]. In addition to the PSA test and morphological study of needle-biopsy cores of the prostate, the development of highly precise less invasive testing methods will clearly be very useful. The proportion of subjects with of normal, inflamed, benign hyperplastic and cancerous prostates in the present study reproduced the Urological Department's usual patient proportions in the MRRC. Thus, our data allow us to evaluate adequately the importance of TE concentrations, $\mathrm{Zn} / \mathrm{TE}$ concentration ratios, and some other TE combinations in EPF for the diagnosis of PCa. As is evident from Table 3 and Table 4, as well as from individual data sets (Figure 1), the $\mathrm{Rb}, \mathrm{Zn}, \mathrm{Zn} / \mathrm{Br}$, $\mathrm{Zn} / \mathrm{Fe}, \mathrm{Zn} / \mathrm{Sr}, \mathrm{ZnRb}$, and $(\mathrm{ZnRb}) / \mathrm{Fe}$ in EPF are potentially the most informative parameters for a differential diagnosis of PCa.

The equations for calculation of such important characteristics of the diagnostic test as "Sensitivity", "Specificity/Selectivity" and "Accuracy" are well known [42]. They comprise:

$$
\begin{gathered}
\text { Sensitivity }=\{\text { True Positives }(\mathrm{TP}) /[\mathrm{TP}+\text { False Negatives }(\mathrm{FN})]\} \times 100 \% \\
\text { Specificity }=\{\text { True Negatives }(\mathrm{TN}) /[\mathrm{TN}+\text { False Positives }(\mathrm{FP})]\} \times 100 \% \\
\text { Accuracy }=[(\mathrm{TP}+\mathrm{TN}) /(\mathrm{TP}+\mathrm{FP}+\mathrm{TN}+\mathrm{FN})] \times 100 \%
\end{gathered}
$$

For example, if "Sensitivity" of a new method of PCa diagnosis is set equal to $100 \%$ the resulting values for "Specificity/Selectivity" and "Accuracy" are presented in Table 5. If "Specificity/Selectivity" of a new method of PCa diagnosis is set equal to $100 \%$ the resulting values for "Sensitivity" and "Accuracy" are also presented in Table 5. The data for "Sensitivity", "Specificity/Selectivity" and 
"Accuracy" can be more balanced if a level of $\geq 80 \%$ for "Sensitivity" is acceptable (Table 5). It should be noted that the number of people (samples) examined was taken into account for calculation of confidence intervals of data presented in Table 5 [42].

From data in Table 5 it follows, after comparison, that levels of "Sensitivity", "Specificity/Selectivity" and "Accuracy" for the Rb, Zn, Zn/Br, Zn/Fe, Zn/Sr, $\mathrm{ZnRb}$, and $(\mathrm{ZnRb}) / \mathrm{Fe}$ in EPF used as PCa biomarkers are better than results from the PSA level blood serum test. Among them the most informative tumor marker is the combination of $\mathrm{Fe}, \mathrm{Rb}$, and $\mathrm{Zn}$ concentrations- $(\mathrm{ZnRb}) / \mathrm{Fe}$. In other words, if level of ( $\mathrm{ZnRb}) / \mathrm{Fe}$ in EPF sample is lower than 5.5, one could diagnose a malignant tumor with an accuracy $96 \% \pm 2 \%$. Thus, using the level of $(\mathrm{ZnRb}) / \mathrm{Fe}$ in an EPF sample as a tumor marker makes it possible to diagnose cancer in the range $91 \%-100 \%$ ) of cases (sensitivity) with specificity/selectivity $96 \% \pm 2 \%$. The high level of specificity/selectivity, $96 \% \pm 2 \%$, means that this test results in a significant decrease in the number of unnecessary biopsies, because on average only $4 \%(100 \%-96 \%=4 \%)$ of prostate biopsies fail to detect PCa (i.e. are false negative) in men who have prostate cancer. Thus, using the proposed test will reduce the number of true negatives after biopsy.

Characteristically, elevated or deficient levels of TEs and electrolytes observed in the EPF of cancerous prostates are discussed in terms of their potential role in the initiation, promotion, or inhibition of prostate cancer. In our opinion, abnormal levels of TE contents and $\mathrm{Zn} / \mathrm{TE}$ ratios in the EPF of cancerous prostates could be the consequences of malignant transformation. Compared to other fluids of the human body, the prostate's secretion contains higher levels of Rb and $\mathrm{Zn}$ and some other TEs. These data suggest that these elements could be involved in prostatic function. The suppressed prostatic function can be both a cause and a consequence of $\mathrm{CP}$ or BPH. Malignant transformation is accompanied by a drastic loss of tissue-specific functional features, which leads to a significant reduction in the content of some elements associated with functional characteristics of the human EPF, including such TEs as Rb and $\mathrm{Zn}$. Increased levels of Fe in EPF of patients with PCa can be explained by blood leakage because of the destruction some blood vessels by malignancy.

It is necessary to keep in mind that biochemical, or in other words functional, changes in prostatic cells are present from the earliest development of malignancy, which precedes any histopathological indication of malignancy, and these biochemical changes persist during progression of the malignancy and remain present in advanced prostate cancer. Thus, $\mathrm{Zn}$ and $\mathrm{Rb}$ depletion is an early step in the cancer proliferation process and $\mathrm{Zn}$ and $\mathrm{Rb}$ depletion in EPF precedes the morphological transformation of cells from being histopathologically normal to cancerous.

In our study the portable device we used for EDXRF analysis, with its ${ }^{109} \mathrm{Cd}$ source for the excitation of X-ray fluorescence in the EPF sample, was developed by ourselves. More powerful devices for EDXRF analysis with X-ray tubes, including "the total reflection" version of the method, allow reliable determina- 
tions of the $\mathrm{Br}, \mathrm{Fe}, \mathrm{Rb}, \mathrm{Sr}$, and $\mathrm{Zn}$ concentrations in a drop of a human body fluid within $10 \mathrm{~min}$ [43]. EDXRF is a fully instrumental and non-destructive method because a drop of EPF is investigated without requiring any sample pretreatment or its consumption. Moreover, it is well known that among the most modern analytical technologies, EDXRF is one of the simplest, fastest, most reliable and efficient of the available techniques for TE determination [43]. There are many different kinds of EDXRF device on the market and technical improvements are frequently announced.

The routine screening for PCa has generally included invasive (by a venipuncture) testing of PSA level in blood serum. The method presented here for $\mathrm{PCa}$ screening is a noninvasive and safe procedure because only requires a drop of EPF. This is obtained during a digital rectal examination using prostate gland massage. Many urologists have successfully and easily obtained EPF this way, so it seems likely that others will be able to do likewise for most of their patients.

All of these advantages, including the elimination of $\mathrm{CP}$ and $\mathrm{BPH}$ as confounding conditions when screening for PCa, along with its "Sensitivity", "Specificity" and "Accuracy" for PCa identification all exceeding 90\%, favor the EDXRF of TEs and their combinations in EPF over the use of PSA levels for this purpose. Also these results suggest a strong possibility that it can replace the PSA level determination in screening for PCa. In our opinion, obtaining the levels of TEs and their combinations in a drop of EPF, using EDXRF, is a fast, reliable, and non-invasive diagnostic tool that can be successfully used by physicians, who are not urologists, at the point-of-care for highly effective PCa screening and as an additional test before prostate gland biopsy. Its advantages have been outlined above. Further we believe it is superior to the PSA level determination for this purpose.

\section{Conclusion}

There is a critical need for a highly reliable, accurate, simplified biomarker and procedure for the screening for prostate cancer, or as an adjunct for the PSA test during the urological examination of patients as candidates for prostate biopsy. In the present work, TE measurements were carried out in the EPF samples from normal, inflamed, hyperplastic, and malignant prostates using the non-destructive, instrumental ${ }^{109} \mathrm{Cd}$ EDXRF micro method developed by us. It was shown that this method is an adequate analytical tool for the non-destructive determination of $\mathrm{Br}, \mathrm{Fe}, \mathrm{Rb}, \mathrm{Sr}$, and $\mathrm{Zn}$ concentrations as well as for calculation of $\mathrm{Zn} / \mathrm{TE}$ concentration ratios and some other TE concentration combinations in the EPF samples of human prostate in normal and some pathological conditions. It was observed that in the EPF of cancerous prostates, levels of $\mathrm{Rb}, \mathrm{Zn}, \mathrm{Zn} / \mathrm{Br}, \mathrm{Zn} / \mathrm{Fe}$, $\mathrm{Zn} / \mathrm{Sr}, \mathrm{ZnRb}$, and $(\mathrm{ZnRb}) / \mathrm{Fe}$ were significantly lower in a comparison with those in the EPF of normal, inflamed, and hyperplastic prostates. It was shown that "Sensitivity", "Specificity" and "Accuracy" of PCa identification using the Rb, $\mathrm{Zn}, \mathrm{Zn} / \mathrm{Br}, \mathrm{Zn} / \mathrm{Fe}$, and $\mathrm{Zn} / \mathrm{Sr}$ levels in the EPF samples was significantly higher 
than that using PSA levels in blood serum. It was concluded that study of the TE levels and their combinations in an EPF drop, obtained by using EDXRF, is a fast, reliable, and non-invasive diagnostic tool that can be successfully used by physicians at the point-of-care for highly effective PCa screening and as an additional test before a prostate gland biopsy.

\section{Acknowledgements}

The author is grateful to Dr. Tatyana Sviridova, Medical Radiological Research Center, Obninsk for supplying EPF samples. The author is also extremely grateful to Dr. Sinclair Wynchank for a very valuable and detailed discussion of the results of this work and his help in English.

\section{Dedicated}

Dedicated to the blessed memory of my good friend Dr. Rolf Zeisler (National Institute of Standards and Technology, Gaithersburg, Maryland, USA), who was the leading scientist in the field of nuclear analytical methods in the life sciences.

\section{Conflicts of Interest}

The author declares no conflicts of interest regarding the publication of this paper.

\section{References}

[1] Taitt, H.E. (2018) Global Trends and Prostate Cancer: A Review of Incidence, Detection, and Mortality as Influenced by Race, Ethnicity, and Geographic Location. American Journal of Men's Health, 12, 1807-1823. https://www.ncbi.nlm.nih.gov/pmc/articles/PMC6199451 https://doi.org/10.1177/1557988318798279

[2] Dasgupta, P., Baade, P.D., Aitken, J.F., Ralph, N., Chambers, S.K., et al. (2019) Geographical Variations in Prostate Cancer Outcomes: A Systematic Review of International Evidence. Frontiers in Oncology, 9, 238.

https://www.ncbi.nlm.nih.gov/pubmed/31024842 https://doi.org/10.3389/fonc.2019.00238

[3] Siegel, R.L., Miller, K.D. and Jemal, A. (2017) Cancer Statistics, 2017. CA: A Cancer Journal for Clinicians, 67, 7-30. https://www.ncbi.nlm.nih.gov/pubmed/28055103 https://doi.org/10.3322/caac.21387

[4] Qi, D., Wu, C., Liu, F., Gu, K., Shi, Z., et al. (2015) Trends of Prostate Cancer Incidence and Mortality in Shanghai, China from 1973 to 2009. Prostate, 75, 1662-1668. https://www.ncbi.nlm.nih.gov/pubmed/26184773 https://doi.org/10.1002/pros.23046

[5] Tkac, J., Gajdosova, V., Hroncekova, S., Bertok, T., Hires, M., et al. (2019) Prostate-Specific Antigen Glycoprofiling as Diagnostic and Prognostic Biomarker of Prostate Cancer. Interface Focus, 9, Article ID: 20180077. https://www.ncbi.nlm.nih.gov/pubmed/30842876 https://doi.org/10.1098/rsfs.2018.0077

[6] Zapała, P., Dybowski, B., Poletajew, S. and Radziszewski, P. (2018) What Can Be Expected from Prostate Cancer Biomarkers: A Clinical Perspective. Urologia Inter- 
nationalis, 100, 1-12. https://www.karger.com/Article/Fulltext/479982 https://doi.org/10.1159/000479982

[7] Sorokin, I. and Mian, B.M. (2015) Risk Calculators and Updated Tools to Select and Plan a Repeat Biopsy for Prostate Cancer Detection. Asian Journal of Andrology, 17, 864-869. https://www.ncbi.nlm.nih.gov/pmc/articles/PMC4814963 https://doi.org/10.4103/1008-682X.156859

[8] Qu, M., Ren, S.C. and Sun, Y.H. (2014) Current Early Diagnostic Biomarkers of Prostate Cancer. Asian Journal of Andrology, 16, 549-554.

https://www.ncbi.nlm.nih.gov/pmc/articles/PMC4104079 https://doi.org/10.4103/1008-682X.129211

[9] Thompson, I.M., Pauler, D.K., Goodman, P.J., Tangen, C.M., Lucia, M.S., et al. (2004) Prevalence of Prostate Cancer among Men with a Prostate-Specific Antigen Level $<$ or $=4.0$ ng per Milliliter. The New England Journal of Medicine, 350, 22392246. https://www.ncbi.nlm.nih.gov/pubmed/15163773 https://doi.org/10.1056/NEJMoa031918

[10] Alotaibi, K.M. (2019) Incidence of Prostate Cancer among Patients with ProstateRelated Urinary Symptoms: A Single Institution Series in 10 Years. Urology Annals, 11, 135-138. https://www.ncbi.nlm.nih.gov/pubmed/31040596 https://doi.org/10.4103/UA.UA_151_18

[11] Hayes, B., Murphy, C., Crawley, A. and O’Kennedy, R. (2018) Developments in Point-of-Care Diagnostic Technology for Cancer Detection. Diagnostics (Basel), 8, 39. https://www.ncbi.nlm.nih.gov/pmc/articles/PMC6023377 https://doi.org/10.3390/diagnostics8020039

[12] Zaichick, V. (2004) INAA and EDXRF Applications in the Age Dynamics Assessment of Zn Content and Distribution in the Normal Human Prostate. Journal of Radioanalytical and Nuclear Chemistry, 262, 229-234.

https://link.springer.com/article/10.1023/B:JRNC.0000040879.45030.4f https://doi.org/10.1023/B:JRNC.0000040879.45030.4f

[13] Zaichick, V. and Zaichick, S. (2013) The Effect of Age on Br, Ca, Cl, K, Mg, Mn, and $\mathrm{Na}$ Mass Fraction in Pediatric and Young Adult Prostate Glands Investigated by Neutron Activation Analysis. Applied Radiation and Isotopes, 82, 145-151.

https://www.ncbi.nlm.nih.gov/pubmed/23994740 https://doi.org/10.1016/j.apradiso.2013.07.035

[14] Zaichick, V. and Zaichick, S. (2013) INAA Application in the Assessment of Ag, Co, $\mathrm{Cr}, \mathrm{Fe}, \mathrm{Hg}, \mathrm{Rb}, \mathrm{Sb}, \mathrm{Sc}, \mathrm{Se}$, and $\mathrm{Zn}$ Mass Fraction in Pediatric and Young Adult Prostate Glands. Journal of Radioanalytical and Nuclear Chemistry, 298, 1559-1566. https://www.researchgate.net/publication/251091633_INAA_application_in_the_ag e_dynamics_assessment_of_Br_Ca_Cl_K_Mg_Mn_and_Na_content_in_the_norma 1_human_prostate https://doi.org/10.1007/s10967-013-2554-3

[15] Zaichick, V. and Zaichick, S. (2013) NAA-SLR and ICP-AES Application in the Assessment of Mass Fraction of 19 Chemical Elements in Pediatric and Young Adult Prostate Glands. Biological Trace Element Research, 156, 357-366.

https://www.ncbi.nlm.nih.gov/pubmed/?term=Biological+Trace+Element+Researc $\underline{\mathrm{h}+156+(2013) \% 3 \mathrm{~A} 357-366}$ https://doi.org/10.1007/s12011-013-9826-1

[16] Zaichick, V. and Zaichick, S. (2013) Use of Neutron Activation Analysis and Inductively Coupled Plasma Mass Spectrometry for the Determination of Trace Elements in Pediatric and Young Adult Prostate. American Journal of Analytical Chemistry, 4, 696-706. https://www.scirp.org/journal/paperinformation.aspx?paperid=40340 
https://doi.org/10.4236/ajac.2013.412084

[17] Zaichick, V. and Zaichick, S. (2014) Relations of Bromine, Iron, Rubidium, Strontium, and Zinc Content to Morphometric Parameters in Pediatric and Nonhyperplastic Young Adult Prostate Glands. Biological Trace Element Research, 157, 195-204. https://www.ncbi.nlm.nih.gov/pubmed/24435825 https://doi.org/10.1007/s12011-014-9890-1

[18] Zaichick, V. and Zaichick, S. (2014) Relations of the Neutron Activation Analysis Data to Morphometric Parameters in Pediatric and Nonhyperplastic Young Adult Prostate Glands. Advances in Biomedical Science and Engineering, 1, 26-42. https://doi.org/10.1111/j.2047-2927.2012.00005.x

[19] Zaichick, V. and Zaichick, S. (2014) Relations of the Al, B, Ba, Br, Ca, Cl, Cu, Fe, K, $\mathrm{Li}, \mathrm{Mg}, \mathrm{Mn}, \mathrm{Na}, \mathrm{P}, \mathrm{S}, \mathrm{Si}$, Sr, and Zn Mass Fractions to Morphometric Parameters in Pediatric and Nonhyperplastic Young Adult Prostate Glands. BioMetals, 27, 333-348. https://www.ncbi.nlm.nih.gov/pubmed/24554283 https://doi.org/10.1007/s10534-014-9716-9

[20] Zaichick, V. and Zaichick, S. (2014) The Distribution of 54 Trace Elements Including Zinc in Pediatric and Nonhyperplastic Young Adult Prostate Gland Tissues. Journal of Clinical and Laboratory Investigation Updates, 2, 1-15.

https://www.jpmpress.com/wp-content/uploads/2018/05/JCLIUV2N1A1-Zaichick. pdf https://doi.org/10.14205/2310-9556.2014.02.01.1

[21] Zaichick, V. and Zaichick, S. (2014) Androgen-Dependent Chemical Elements of Prostate Gland. Andrology and Gynecology: Current Research, 2, 2.

https://www.scitechnol.com/androgendependent-chemical-elements-of-prostate-gla nd-G1af.php?article_id=1902 https://doi.org/10.4172/2327-4360.1000121

[22] Zaichick, V. and Zaichick, S. (2015) Differences and Relationships between Morphometric Parameters and Zinc Content in Nonhyperplastic and Hyperplastic Prostate Glands. British Journal of Medicine and Medical Research, 8, 692-706.

http://www.sciencedomain.org/index.php?/abstract/9328 https://doi.org/10.9734/BJMMR/2015/17572

[23] Zaichick, V. (2014) The Prostatic Urethra as a Venturi Effect Urine-Jet Pump to Drain Prostatic Fluid. Medical Hypotheses, 83, 65-68.

https://www.ncbi.nlm.nih.gov/pubmed/?term=Zaichick+V.++Med+Hypotheses +20 14\%3B83\%3A65-68 https://doi.org/10.1016/j.mehy.2014.04.006

[24] Mackenzie, A.R., Hall, T. and Whitmore Jr., W.F. (1962) Zinc Content of Expressed Human Prostate Fluid. Nature (London), 193, 72-73.

https://doi.org/10.1038/193072a0

[25] Marmar, J.L., Katz, S., Praiss, D.E. and De Benedictis, T.J. (1980) Values for Zinc in Whole Semen, Fraction of Split Ejaculate and Expressed Prostatic Fluid. Urology, 16, 478-480. https://doi.org/10.1016/0090-4295(80)90599-3

[26] Zaichick, V., Tsyb, A., Dunchik, V.N. and Sviridova, T.V. (1981) Method for Diagnostics of Prostate Diseases. Certificate of Invention No. 997281 (30.03.1981), Russia.

[27] Zaichick, V., Sviridova, T. and Zaichick, S. (1996) Zinc Concentration in Human Prostatic Fluid: Normal, Chronic Prostatitis, Adenoma, and Cancer. International Urology and Nephrology, 28, 687-694. https://doi.org/10.1007/BF02552165 https://www.ncbi.nlm.nih.gov/pubmed/9061429

[28] Zaichick, V., Zaichick, S. and Davydov, G. (2016) Method and Portable Facility for 
Measurement of Trace Element Concentration in Prostate Fluid Samples Using Radionuclide-Induced Energy-Dispersive X-Ray Fluorescent Analysis. Nuclear Science and Technology, 27, Article No. 136. https://doi.org/10.1007/s41365-016-0133-3 https:/link.springer.com/article/10.1007/s41365-016-0133-3

[29] Zaichick, V. and Zaichick, S. (2018) Effect of Age on the Br, Fe, Rb, Sr, and Zn Concentrations in Human Prostatic Fluid Investigated by Energy-Dispersive X-Ray Fluorescent Microanalysis. MicroMedicine, 6, 94-104.

http://www.journals.tmkarpinski.com/index.php/mmed/citationstylelanguage/get/a ssociacao-brasileira-de-normas-tecnicas?submissionId $=80$

[30] Zaichick, V. and Zaichick, S. (2018) Trace Element Concentrations in the Expressed Prostatic Secretion of Normal and Hyperplastic Prostate. Journal of Urology and Nephrology Studies, 1, 53-59. https://doi.org/10.32474/JUNS.2018.01.000112 https://lupinepublishers.com/urology-nephrology-journal/abstracts/trace-element-c oncentra-

tions-in-the-expressed-prostatic-secretion-of-normal-and-hyperplastic-prostate.ID. 000112.php

[31] Zaichick, V. and Zaichick, S. (2018) Trace Elements of Expressed Prostatic Secretions as a Source for Biomarkers of Prostatic Cancer. Journal of Clinical Research in Oncology, 1, 1-7.

https://asclepiusopen.com/journal-of-clinical-research-in-oncology/volume-1-issue -1/7.php

[32] Zaichick, V. and Zaichick, S. (2018) Br, Fe, Rb, Sr, and Zn Levels in the Prostatic Secretion of Patients with Chronic Prostatitis. International Archives of Urology and Complications, 4, 046. https://doi.org/10.23937/2469-5742/1510046

https://clinmedjournals.org/articles/iauc/international-archives-of-urology-and-co mplications-iauc-4-046.php?jid=iauc

[33] Zaichick, V. and Zaichick, S. (2019) Significance of Trace Element Quantities in the Prostatic Secretion of Patients with Chronic Prostatitis and Prostate Cancer. Journal of Biomedical Research and Reviews, 2, 56-61.

https://innovationinfo.org/articles/JBRR/JBRR-122.pdf https://doi.org/10.20517/2394-4722.2019.07

[34] Zaichick, V. and Zaichick, S. (2019) Ratio of Zinc to Bromine, Iron, Rubidium, and Strontium Concentration in the Prostatic Fluid of Patients with Benign Prostatic Hyperplasia. Acta Scientific Medical Sciences, 3, 49-56. https://www.actascientific.com/ASMS/pdf/ASMS-03-0290.pdf https://doi.org/10.14302/issn.2372-6601.jhor-19-3094

[35] Zaichick, V. and Zaichick, S. (2019) Ratio of Zinc to Bromine, Iron, Rubidium, and Strontium Concentration in Expressed Prostatic Secretions as a Source for Biomarkers of Prostatic Cancer. American Journal of Research, 5-6, 140-150. https://journalofresearch.us/2019-5-6-issue-of-the-journal

[36] Zaichick, V. and Zaichick, S. (2019) Some Trace Element Contents and Ratios in Prostatic Fluids as Ancillary Diagnostic Tools in Distinguishing between the Benign Prostatic Hyperplasia and Chronic Prostatitis. Archives of Urology, 2, 12-20. https://www.sryahwapublications.com/archives-of-urology/pdf/v2-i1/4.pdf https://doi.org/10.20517/2394-4722.2019.07

[37] Zaichick, V. and Zaichick, S. (2019) Ratio of Zinc to Bromine, Iron, Rubidium, and Strontium Concentration in the Prostatic Fluid of Patients with Chronic Prostatitis. Global Journal of Medical Research $(F), 19,9-15$. https://globaljournals.org/GJMR_Volume19/3-Ratio-of-Zinc-to-Bromine.pdf

[38] Zaichick, V. and Zaichick, S. (2019) Significance of Trace Element Quantities in the 
Prostatic Secretion of Patients with Benign Prostatic Hyperplasia and Prostate Cancer. Journal of Cancer Metastasis and Treatment, 5, 48.

https://jcmtjournal.com/article/view/3104 https://doi.org/10.20517/2394-4722.2019.07

[39] Zaichick, V. and Zaichick, S. (2019) Some Trace Element Contents and Ratios in Prostatic Fluids as Ancillary Diagnostic Tools in Distinguishing between the Chronic Prostatitis and Prostate Cancer. Medical Research and Clinical Case Reports, 3, 1-10. https://scientiaricerca.com/srmrcr/SRMRCR-03-00052.php

[40] Zaichick, V. (1995) Applications of Synthetic Reference Materials in the Medical Radiological Research Centre. Fresenius Journal of Analytical Chemistry, 352, 219-223. https://doi.org/10.1007/BF00322330

[41] Hjertholm, P., Fenger-Gron, M., Vestergaard, M., Christensen, M.B., Borre, M., et al. (2015) Variation in General Practice Prostate-Specific Antigen Testing and Prostate Cancer Outcomes: An Ecological Study. International Journal of Cancer, 136, 435-442. https://www.ncbi.nlm.nih.gov/pubmed/24905402 https://doi.org/10.1002/ijc.29008

[42] Genes, V.S. (1967) Simple Methods for Cybernetic Data Treatment of Diagnostic and Physiological Studies. Nauka, Moscow.

[43] Rossmann, M., Zaichick, S. and Zaichick, V. (2016) Determination of Key Chemical Elements by Energy Dispersive X-Ray Fluorescence Analysis in Commercially Available Infant and Toddler Formulas Consumed in UK. Nutrition and Food Technology: Open Access, 2, 1-7. https://doi.org/10.16966/2470-6086.130 https://sciforschenonline.org/journals/nutrition-food/NFTOA-2-130.php 